\title{
Further Great Gray Owl Records
}

\author{
Compiled by C. Stuart Houston, Saskatoon
}

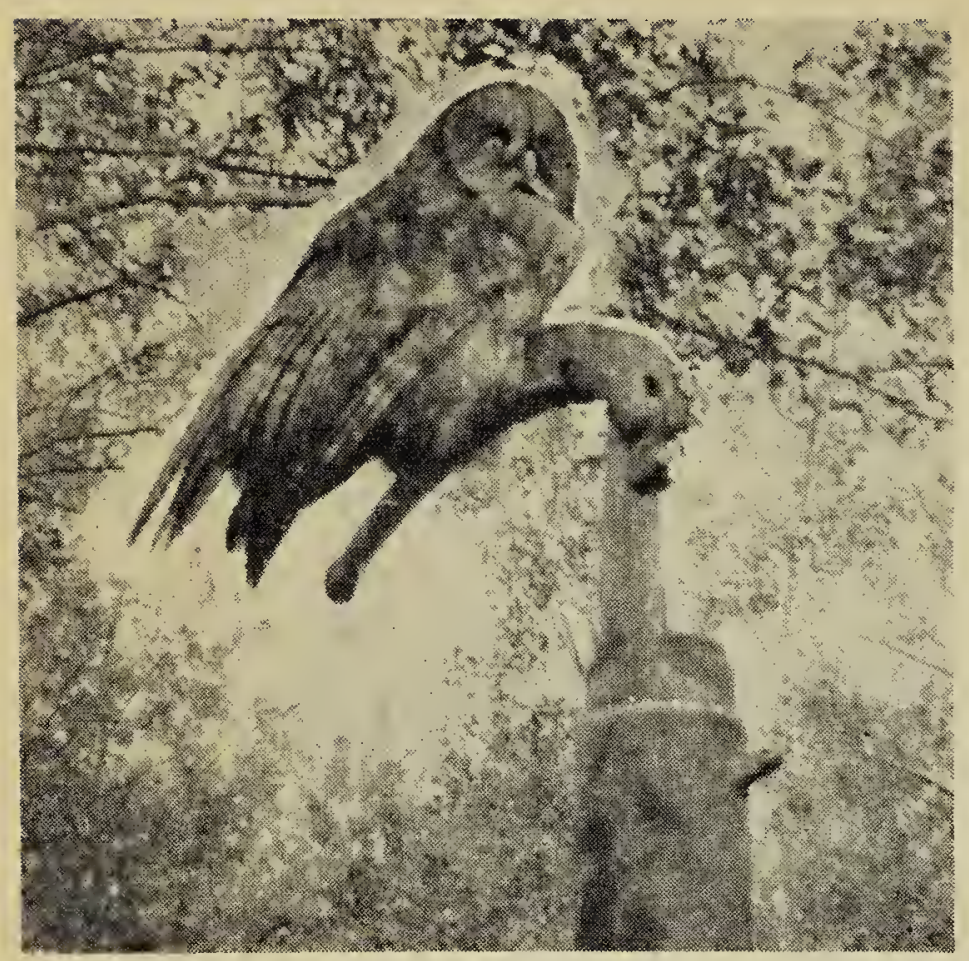

Photo by Jenny
Great Gray Owl, Sept. 5, 1960

When I visited the High Hill district northeast of Kelvington on January 2, 1960, to band the Barred Owl captured by the Waycheshens, Anton and Steve Waycheshen reported that a Great Gray Owl had been seen the previous day at nearby Warner Lake. Although a search that day failed to disclose the Great Gray, it was seen again the next day by the Waycheshens. Thereafter, it was seen in the same area nearly every Saturday night all winter.

That this bird may have remained in the area to nest is suggested by the following information forwarded by P. J. (Bob) Fraser of Kelvington. On September 5, 1960, four Great Gray Owls (presumably a family group) appeared at the farm of Arvid Lindgren, five miles north and three miles east of Kelvington where Miss Jenny Minky photographed one of these rare owls resting on a pump handle. Miss Minky felt that all four birds were young birds "as they were not very strong on the wing." They flew from the farmyard down to a creek where they lit on some low scrub. At the time, she could hear other owls calling from up the creek and presumed these to be parent birds.

Bill Richards forwarded another report that Great Gray Owls are seen winter and summer on the farm of Jens Knutson in the Etomami district, 20 miles southeast of Hudson Bay, Saskatchewan. Ron Lafreniere of Saskatoon saw these birds several times while visiting the farm - including one seen at 100 feet while he was hunting moose there in the fall of 1960. A Great Gray was found dead in a mink trap by Knutson in the winter of 1959-60.

EDITOR'S NOTE: See also the report of a Great Gray Owl seen north of La Ronge by Douglas and Dorothy Wade, page 10 of this issue.

\section{Screech Owl at Regina}

\section{by Bill Fleming, Regina}

On October 17, 1961, the first reported sighting of a Screech Owl (Otus asio) in the Regina district for 20 years was recorded. Rick Sanderson and I sighted a Screech Owl sitting about nine feet off the ground in a small spruce tree in the grounds of a large home on the edge of the Regina Waterfowl Park. Mr. Elmer Fox later confirmed the sighting, although he was unable to take pictures because of the lack of light and a telephoto lens. The owl, a bird in the red phase, was gone the next day as the.weather turned cold.
The Screech Owl is a small owl which occurs in two colour phases, irrespectivo of age, sex, or seasongrey and rufous. One is rich brown and white with much fine pattern giving a grey effect, the other has the brown replaced by bright rufous, almost brick red.

In western Canada, the Screech Owl is commonly found only in southern Manitoba and British Columbia. Records for Regina are few. Miss Margaret Belcher in Birds of Regina (1961. Spec. Pub. No. 3 (Continued on page 33 ) 